This item was submitted to Loughborough's Research Repository by the author.

Items in Figshare are protected by copyright, with all rights reserved, unless otherwise indicated.

\title{
Synthesis, crystal structure, and cytotoxicity studies of titanacalix[4 and 8]arene complexes
}

\section{PLEASE CITE THE PUBLISHED VERSION}

https://doi.org/10.1039/c8dt01992d

\section{PUBLISHER}

(c) Royal Society of Chemistry

\section{VERSION}

AM (Accepted Manuscript)

\section{PUBLISHER STATEMENT}

This work is made available according to the conditions of the Creative Commons Attribution-NonCommercialNoDerivatives 4.0 International (CC BY-NC-ND 4.0) licence. Full details of this licence are available at: https://creativecommons.org/licenses/by-nc-nd/4.0/

\section{LICENCE}

CC BY-NC-ND 4.0

\section{REPOSITORY RECORD}

Miller-Shakesby, David M., Shubhanchi Nigam, David L. Hughes, Enrique Lopez-Estelles, Mark R.J. Elsegood, Cawthorne Cawthorne, Stephen J. Archibald, and Carl Redshaw. 2019. "Synthesis, Crystal Structure, and Cytotoxicity Studies of Titanacalix[4 and 8]arene Complexes". figshare. https://hdl.handle.net/2134/33618. 


\section{Synthesis, Crystal Structure, and Cytotoxicity Studies of titanacalix[4 and 8]arene Complexes}

David M. Miller-Shakesby ${ }^{a}$, Shubhanchi Nigam ${ }^{a, b}$, David L. Hughes ${ }^{c}$, Enrique LopezEstelles $^{d}$, Mark R. J. Elsegood ${ }^{d}$, Christopher J. Cawthorne, ${ }^{b, e}$ Stephen J. Archibald ${ }^{a, b *}$ and Carl Redshaw ${ }^{a *}$

${ }^{a}$ Chemistry, School of Mathematics and Physical Sciences, University of Hull, Hull, HU6 7RX, U.K.

${ }^{b}$ Positron Emission Tomography Research Centre, University of Hull, Cottingham Road, Hull, HU6 7RX, UK. 'School of Chemistry, University of East Anglia, Norwich, NR4 7TJ, U.K.

${ }^{d}$ Chemistry Department, Loughborough University, Loughborough, Leicestershire, LE11 3TU.

e School of Life Sciences, University of Hull, Hull, HU6 7RX, U.K.

Reaction of 5,11,17,23-tetra-tert-butyl-dihydroxy-26,28-bis(2-pentoxy)calix[4]arene $\left(\mathrm{L}(\mathrm{OH})_{2}(\mathrm{Opentyl})_{2}\right)$ with $\left[\mathrm{TiCl}_{4}\right]$ afforded the dichlorotitanoacalix[4]arene complex $\left[\mathrm{TiCl}_{2} \mathrm{~L}(\mathrm{O})_{2}(\text { Opentyl })_{2}\right]$ (1) in good yield. Hydrolysis of $\mathbf{1}$ led to the isolation of the complex $\left\{\left[\mathrm{TiL}(\mathrm{O})_{3}(\mathrm{Opentyl})\right]_{2}(\mu-\mathrm{OH})(\mu-\mathrm{Cl})\right\} \quad$ (2). Reaction $\quad$ of $\quad 49,50,51,52,53,54,55,56-$ octapropoxycalix[8]arene $\left(\mathrm{L}^{\prime}(\mathrm{Opropyl})_{8}\right)$ with $\left[\mathrm{TiCl}_{4}\right]$ in refluxing toluene afforded, following work-up, a 35:65 mixture (3) of the complex $\left[\mathrm{Ti}(\mathrm{NCMe}) \mathrm{Cl}_{2}[\mathrm{TiCl}(\mu-\mathrm{O})]_{2} \mathrm{~L}^{\prime}\right]$ and the silicone grease derived complex $\left.[\mathrm{Ti}(\mathrm{NCMe}) \mathrm{Cl}]_{2}[\mathrm{Ti}(\mu-\mathrm{O})]_{2}\left[\mathrm{OSi}\left(\mathrm{CH}_{3}\right)_{2} \mathrm{OSi}\left(\mathrm{CH}_{3}\right)_{2} \mathrm{O}\right] \mathrm{L}^{\prime}\right]$ in which the grease replaces two chloride ligands. The molecular structures of $\mathbf{1 \cdot 2} \mathbf{M e C N}, \mathbf{2} \cdot \mathbf{7} 1 / \mathbf{4} \mathbf{M e C N}$, and $\mathbf{3} \cdot \mathbf{1 0 M e C N}$ have been determined. The complexes were studied using in vitro cell assays and were found to have $\mathrm{CC}_{50}$ values in the range 111 - $186 \mu \mathrm{M}$, i.e. they have low toxicity. 


\section{Introduction}

The biological potential of calix[ $n$ ]arenes is now well recognised. [1] They have been utilized as scaffolds in the battles against TB, HIV and cancer as well as extensively as biosensors.[2] This interest stems from the ability to readily tune properties such as solubility and also from the ability to append functional groups/motifs of biological interest. In the case of metallocalixarenes, one important aspect to address is their hydrolytic stability and, in particular, whether or not the metal remains bound to the calixarene under physiological conditions. We are interested in exploiting the many attributes of calix[ $n]$ arenes to develop new scaffolds capable of selectivity for the receptors overexpressed on the surface of cancer cells.[2b, 3] Given that, despite it's successes, cisplatin and derivatives such as carboplatin have major limitations, such as high instances of drug resistance, adverse side effects, and a tendency to only work against treatable cancers, there is a drive to develop new agents based on metals other than platinum. A number of titanium complexes bearing salen/salen-type ligation (see Chart 1) have been shown to exhibit promising anti-cancer effects, and have outperformed cisplatin.[4] In this study, we explore the potential of a dichlorotitanocalix[4]arene complex derived from a 1,3-dialkoxycalix[4]arene precursor and have identified a hydrolysis product. Extension of the work to a calix[8]arene system resulted in the isolation of a silicone grease derived complex. The incorporation if silicone grease into molecular structures has been reviewed. [5] Titanocalix[n]arenes are known, [6] but have only previously been exploited for their catalytic potential in $\alpha$-olefin polymerization or the ring opening polymerization (ROP) of cyclic esters. [7] We also note that this type titanocalix[4]arene has been grafted onto silica and employed in olefin epoxidation by the group of Katz. [8] 


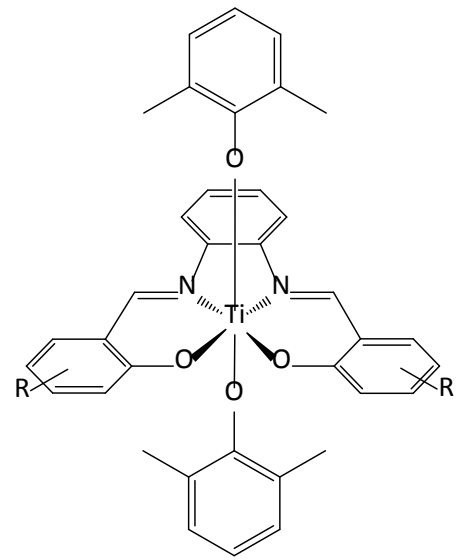
Where: $\quad \mathrm{R}=4-\mathrm{Me} \quad-\mathrm{Lig}_{1} \mathrm{Ti}\left(\mathrm{OArMe}_{2}\right)_{2}$
$\mathrm{R}=\mathrm{H} \quad-\mathrm{Lig}_{2} \mathrm{Ti}\left(\mathrm{OArMe}_{2}\right)_{2}$
$\mathrm{R}=4-\mathrm{Cl} \quad-\mathrm{Lig}_{3} \mathrm{Ti}\left(\mathrm{OArMe}_{2}\right)_{2}$

Chart 1. The structures of a number of Ti-SALAN complexes that exhibit cytotoxicity 10 to 20-fold greater than that of cisplatin. [4]
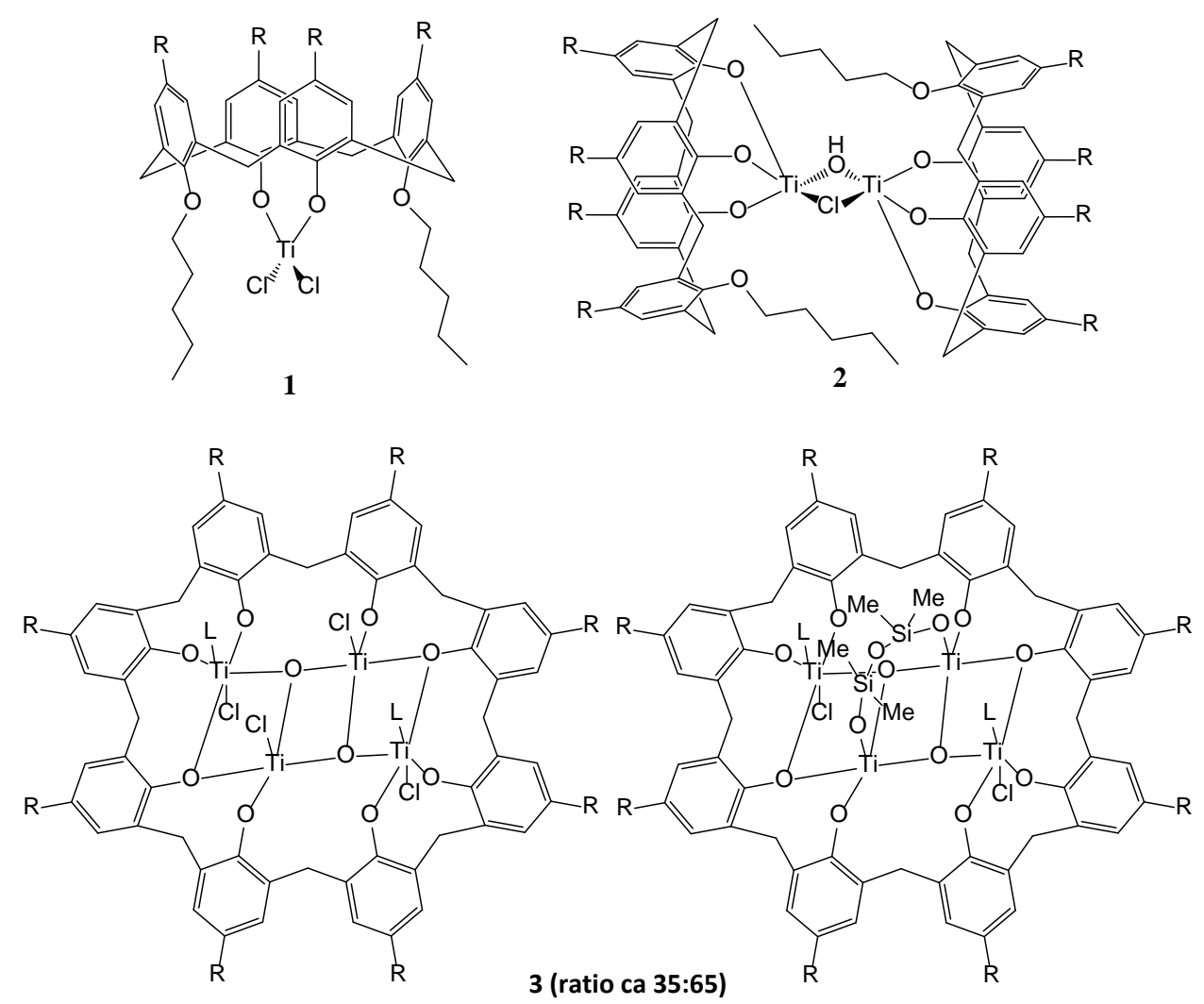

Chart 2. Titanocalix $[n]$ arenes studied herein $(\mathrm{R}=t \mathrm{Bu}, \mathrm{L}=\mathrm{NCMe})$. 
Results and Discussion

\section{Synthesis and characterisation}

The

pro-ligand

5,11,17,23-tetra-tert-butyl-dihydroxy-26,28-bis(2-

pentoxy)calix[4]arene $\left(\mathrm{L}(\mathrm{OH})_{2}(\mathrm{Opentyl})_{2}\right)$ was prepared according to the previously described method. [3b, 7k] Refluxing a toluene solution of $\left(\mathrm{L}(\mathrm{OH})_{2}(\mathrm{Opentyl})_{2}\right)$ and [ $\left.\mathrm{TiCl}_{4}\right]$ for several hours, followed by removal of solvent, extraction of the residue into warm acetonitrile and allowing the solution to cool and stand at ambient temperature afforded deep red plates over the course of several days. A crystal suitable for a structure determination was chosen, and the molecular structure determined. The structure of $\left[\mathrm{TiCl}_{2} \mathrm{~L}(\mathrm{O})_{2}(\mathrm{Opentyl})_{2}\right] \cdot 2 \mathrm{MeCN}(\mathbf{1})$ is shown in Figure 1; selected bond lengths and angles are given in the caption.

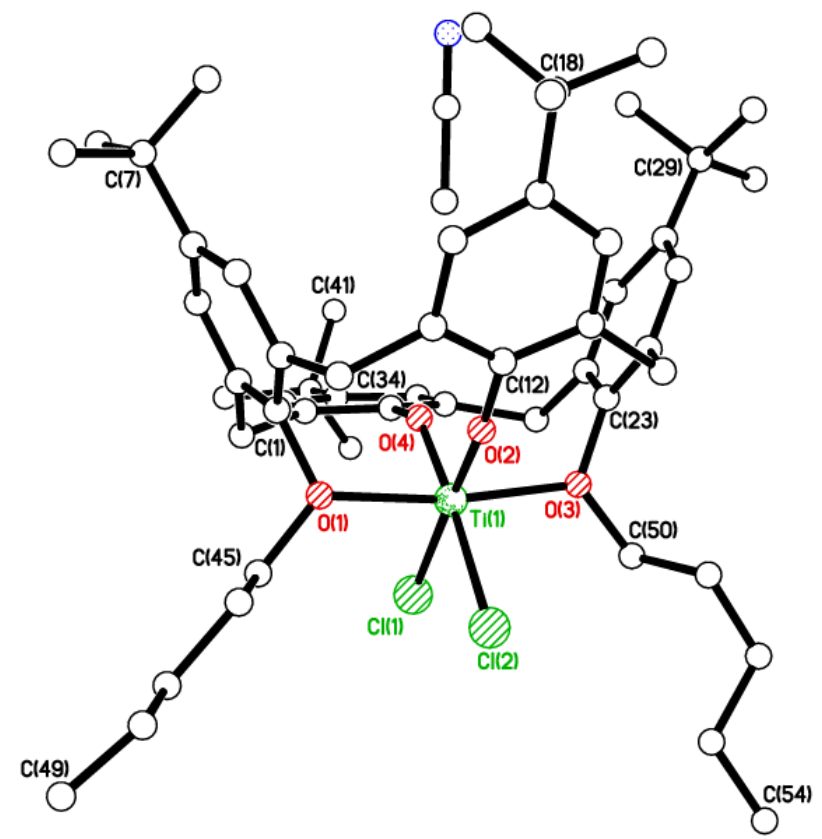

Figure 1. Crystal structure of $\mathbf{1 \cdot 2 M e C N}$. The second $\mathrm{MeCN}$ is not visible due to modelling as a diffuse area of electron density. Selected bond lengths ( $\AA$ ) and angles $\left(^{\circ}\right): \operatorname{Ti}(1)-\mathrm{O}(1)$ 2.118(8), $\mathrm{Ti}(1)-\mathrm{O}(2)$ 1.786(8), $\mathrm{Ti}(1)-\mathrm{O}(3)$ 2.101(8), $\mathrm{Ti}(1)-\mathrm{O}(4)$ 1.805(8), Ti(1)-Cl(1) 2.342(4), Ti(1)-Cl(2) 2.334(4); Cl(1)-Ti(1)-Cl(2) 85.78(15), $\mathrm{O}(1)-\mathrm{Ti}(1)-\mathrm{Cl}(1)$ 92.8(2), O(1)- Ti(1)-O(3) 171.4(3). 
The titanium centre is best described as distorted octahedral bound by two chlorides and four calixarene oxygen atoms, the calix[4]arene adopting a conformation with three rings 'up' and one 'out'. The Ti-O phenolate bonds at 1.786(8) and 1.805(8) $\AA$ are typical and are significantly shorter than those of the Ti-O ether-type linkages [2.118(8) and 2.101(8) Å]. In the related structures $\left[\mathrm{TiCl}_{2} \mathrm{LO}_{2}(\mathrm{OR})_{2}\right](\mathrm{R}=\mathrm{Me}, \mathrm{Et}, n \mathrm{Pr}$, iBu; CCDC refcodes: NIFQIC, XUSAK, XUWSEO, and XUWRUD respectively), the Ti-O(phenoxy) bond lengths are ca. $1.78-1.90 \AA$ and Ti-O(ether) ca. $2.09-2.18 \AA$. $[7 \mathrm{k}]$

In order to determine the air stability of $\mathbf{1}$, a solution of $\mathbf{1}$ was stirred under air for $2 \mathrm{~h}$, whereupon following work-up, an orange/red complex was isolated. If the complex is taken up in acetonitrile, small prisms can be grown over several days. The molecular structure is shown in Figure 2, with selected bond lengths and angles given in the caption. The structure was identified as the complex $\left\{\left[\mathrm{TiL}(\mathrm{O})_{3}(\mathrm{Opentyl})\right]_{2}(\mu-\mathrm{OH})(\mu-\right.$ Cl)\} (2), which contains a bridging chloride and a bridging hydroxide ligand. The bridging hydroxide ligand may have been part chloride, but this was not modelled. Seven and a quarter acetonitrile solvate molecules complete the asymmetric unit to

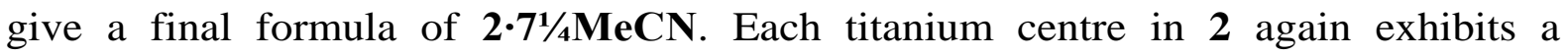
distorted octahedral environment, and each is bound by a calix[4]arene ligand bearing only one pentoxy group. These pentoxy groups reside in trans positions above and below the $\mathrm{Ti}_{2}(\mu-\mathrm{OH}) \mu-\mathrm{Cl}$ core. An acetonitrile molecule resides in each of the calix[4]arene cavities, whilst a further acetonitrile is involved in H-bonding to the bridging hydroxide group. Two and quarter other exo acetonitriles have been modelled as point atoms, and two exo acetonitriles were modelled as diffuse electron density by the Platon Squeeze procedure. $[9,10]$ We note that a route to monofunctionalised 
calix[4]arenes via removal of an ether functionality using $\mathrm{TiCl}_{4}$ has been reported by Floriani and coworkers. [6d] Floriani et al identified $\mathrm{CH}_{3} \mathrm{Cl}$ in their reaction and suggested this was the result of capture of the leaving group by the $\mathrm{Cl}^{-}$nucleophile. For 2, similar loss of two equivalents of pentylchloride is invoked and to balance the hydrolysis reaction, one equivalent of $\mathrm{HCl}$ is also lost.

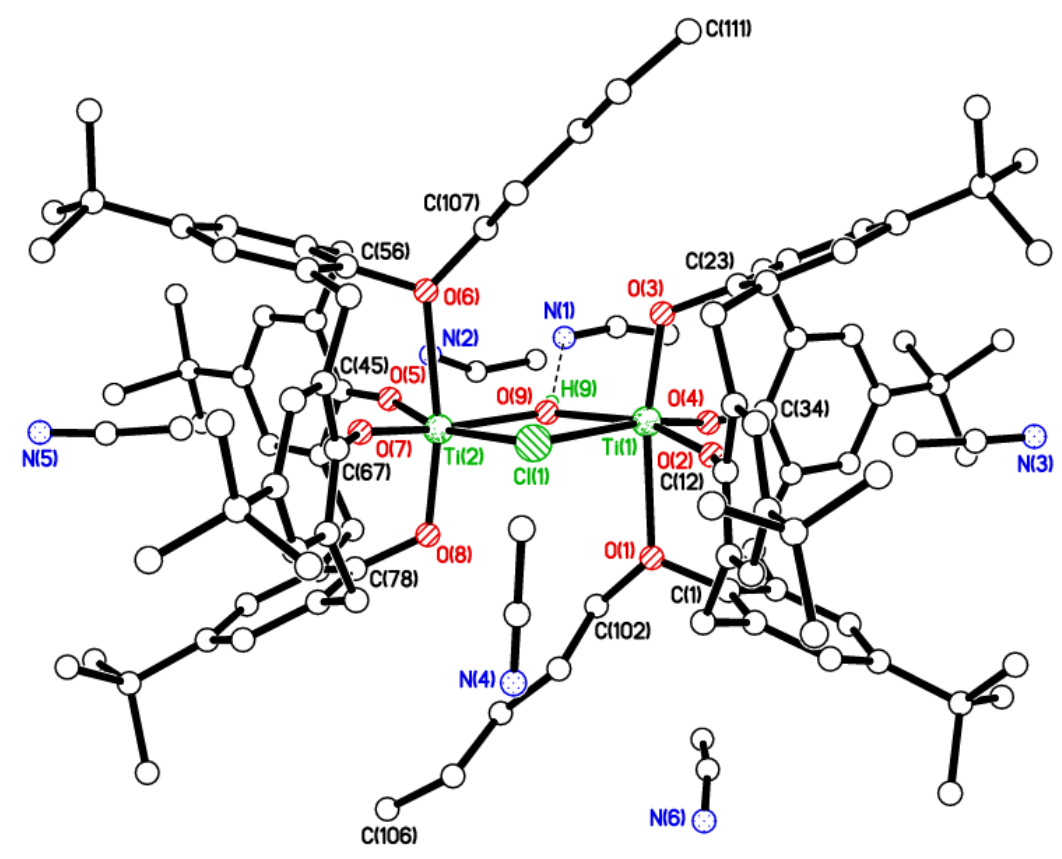

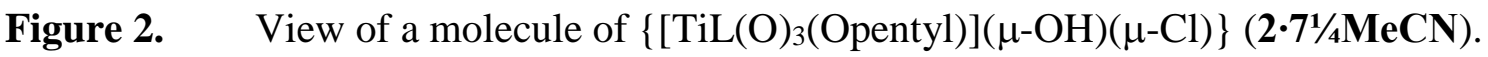

Some MeCN molecules are not visible due to modelling as diffuse areas of electron density. Selected bond lengths $(\AA)$ and angles $\left(^{\circ}\right)$ : Ti(1)-O(1) 2.363(7), Ti(1)-O(2) 1.814(6), Ti(1)O(3) 1.864(7), Ti(1)-O(4) 1.796(7), Ti(1)-Cl(1) 2.514(3), Ti(1)-O(9) 2.061(7); Cl(1)-Ti(1)Cl(2) 85.67(10), O(9)-Ti(1)-Cl(1) 90.2(3), O(1)-Ti(1)-O(3) 169.7(3), O(5)-Ti(1)-O(7) 104.5(3).

Use of 49,50,51,52,53,54,55,56-octapropoxycalix[8]arene (L'(Opropyl)8)

Given the removal of the ether groups at the lower rim in calix[4]arene chemistry, we were interested to investigate how $\mathrm{TiCl}_{4}$ would react in combination with 
49,50,51,52,53,54,55,56-octapropoxycalix[8]arene (L'(Opropyl) $\left.)_{8}\right)$. On heating a toluene solution of $\left(\mathrm{L}^{\prime}(\mathrm{Opropyl})_{8}\right)$ and $\left[\mathrm{TiCl}_{4}\right]$ for several hours and then, following removal of solvent, extracting the residue into warm acetonitrile red needles grew over the course of several days. In the ${ }^{1} \mathrm{H}$ NMR spectrum, there was no evidence of propyl groups whilst a peak at $\delta 0.14 \mathrm{ppm}$ was initially thought to be silicone grease. Surprisingly, a molecular structure determination revealed a calix[8]arene ligand binding four titanium centres (Figures $3 \mathbf{\&}$ 4), the latter forming a three step $\mathrm{Ti}_{4} \mathrm{O}_{4}$ ladder central moiety (Figures 5 \& 6). The central two titanium atoms were either coordinated to one chloride ion each (34.6(3) \% occupancy), or linked by a $\mathrm{OSi}(\mathrm{Me})_{2} \mathrm{OSi}(\mathrm{Me})_{2} \mathrm{O}$ (65.4(3) \% occupancy) which accounts for the peak at $\delta 0.14$ ppm in the ${ }^{1} \mathrm{H}$ NMR spectrum, and is thought to originate from the use of silicone grease. We note that silicone grease has proved to be a source of some interesting coordination complexes. [5, 9] Two chlorides and two bound MeCN solvate molecules complete the structure of $\mathbf{3 \cdot 1 0 M e C N}$ with 10 unbound MeCNs also present.

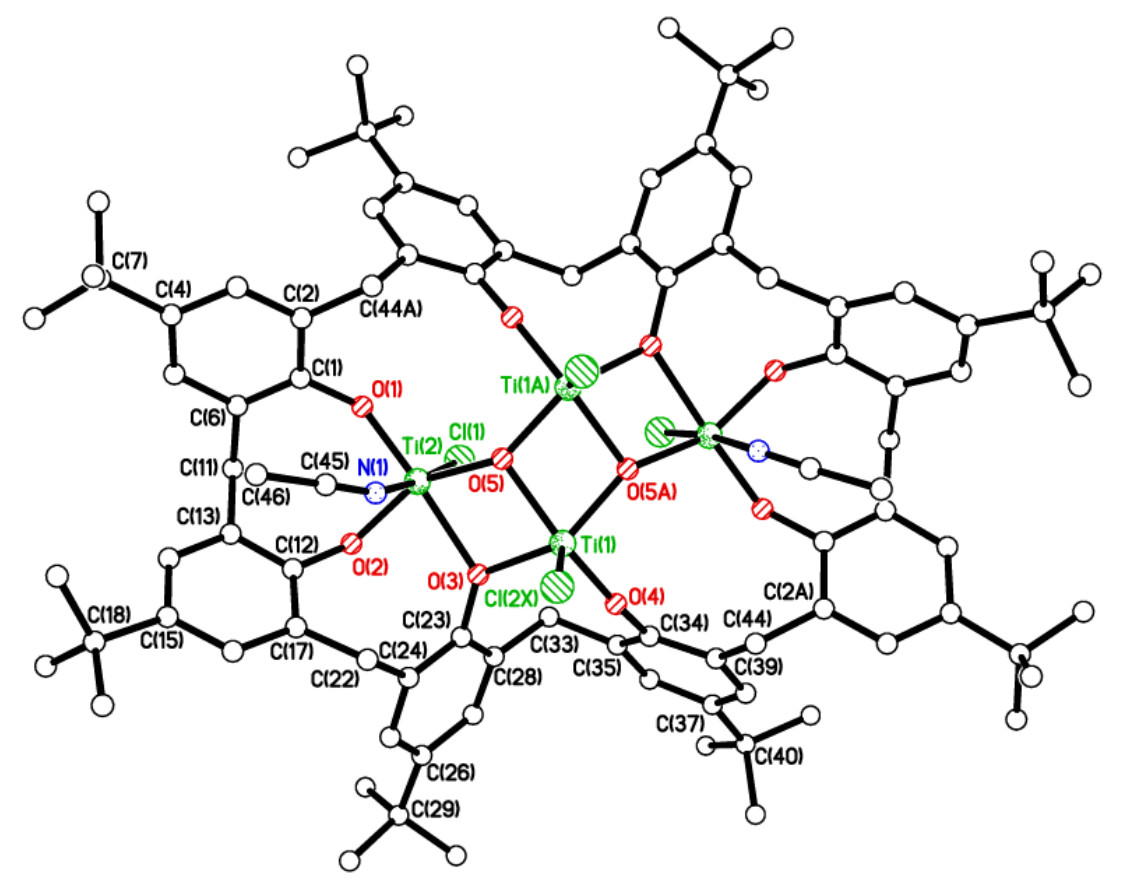


Figure 3. Top view of a molecule of $[\mathrm{Ti}(\mathrm{NCMe}) \mathrm{Cl}]_{2}[\mathrm{TiCl}]_{2}[\mu-$ O $]_{2}[5,11,17,23,29,35,41,47$-tetra-tert-butyl-49,50,51,52,53,54,55,56-

octaoxocalix[8]arene] in $\mathbf{3 \cdot 1 0 M e C N}$. MeCN of crystallisation omitted for clarity. Selected bond lengths $(\AA)$ and angles $\left(^{\circ}\right)$ : Ti(1)-O(3) 1.9502(16), Ti(1)-O(4) 1.7828(16), Ti(1)-O(5) 1.9967(16), Ti(1)-O(5A) 1.9026(16), Ti(1)-Cl(2X) 2.269(3), $\mathrm{Ti}(2)-\mathrm{O}(1)$ 1.8118(16); $\mathrm{Ti}(2)-\mathrm{O}(2)$ 1.8180(16), $\mathrm{Ti}(2)-\mathrm{O}(3)$ 2.1713(15), $\mathrm{Ti}(2)-\mathrm{O}(5)$ 1.9464(17), $\quad \mathrm{Ti}(2)-\mathrm{N}(1) \quad 2.276(2), \quad \mathrm{Ti}(2)-\mathrm{Cl}(1) \quad 2.2981(8), \quad \mathrm{Cl}(2 \mathrm{X})-\mathrm{Ti}(1)-\mathrm{O}(5)$ 105.08(10), O(3)-Ti(1)-O(5) 76.37(7), O(3)-Ti(2)-O(5) 72.45(6), Cl(1)-Ti(2)-O(5) 96.01(6), $\mathrm{Cl}(1)-\mathrm{Ti}(2)-\mathrm{N}(1)$ 174.14(14).

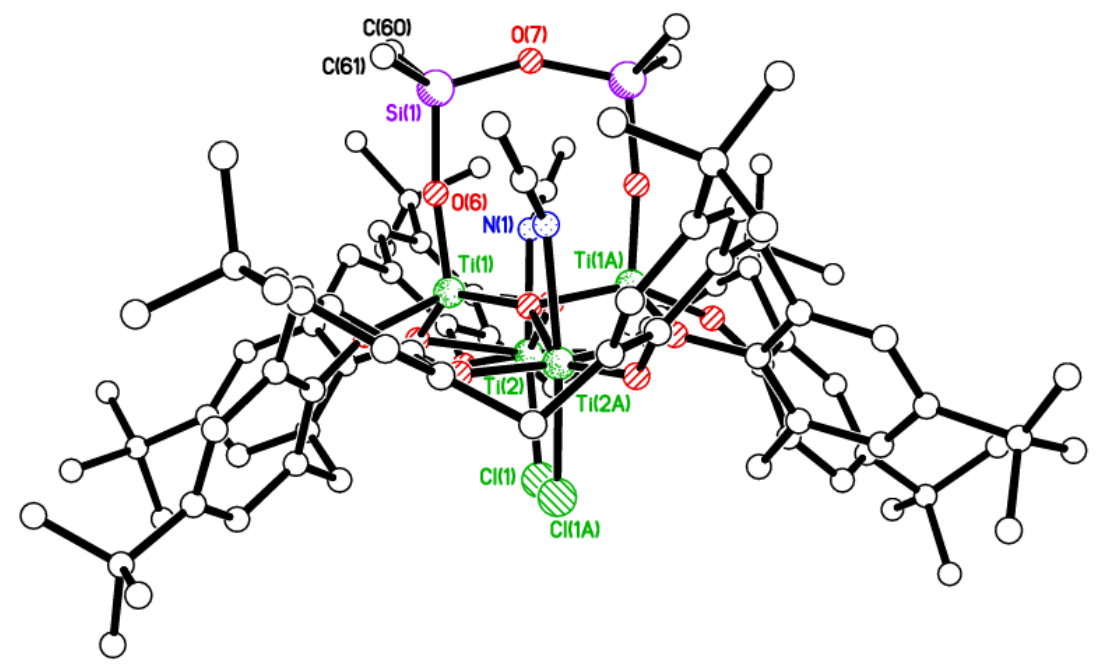

Figure 4. Side view of a molecule of $[\mathrm{Ti}(\mathrm{NCMe}) \mathrm{Cl}]_{2}[\mathrm{Ti}]_{2}[\mu-\mathrm{O}]_{2}[\mu-$ $\left.\mathrm{OSi}\left(\mathrm{CH}_{3}\right)_{2} \mathrm{OSi}\left(\mathrm{CH}_{3}\right)_{2} \mathrm{O}\right][5,11,17,23,29,35,41,47$-tetra-tert-butyl49,50,51,52,53,54,55,56-octaoxocalix[8]arene] in $\mathbf{3} \cdot \mathbf{1 0 M e C N}$. MeCN of crystallisation omitted for clarity. 


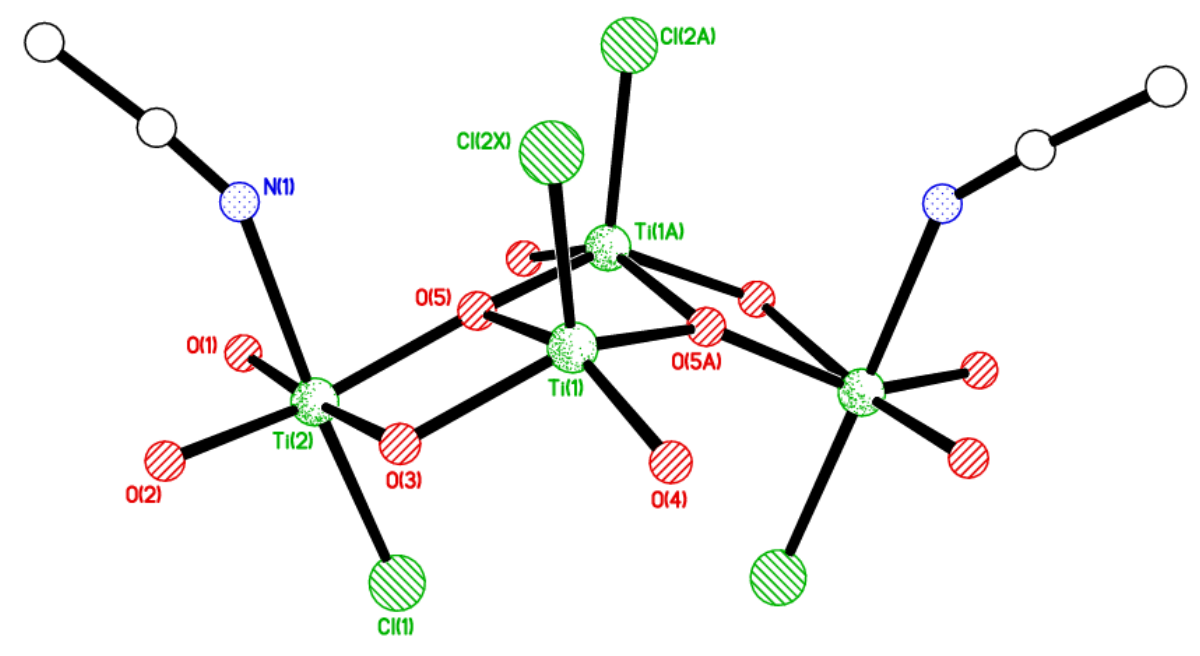

Figure 5. View of the core $\mathrm{Ti}_{4} \mathrm{O}_{4}$ ladder moiety present in (3-10MeCN) showing the molecule with four chlorides, and two MeCNs.

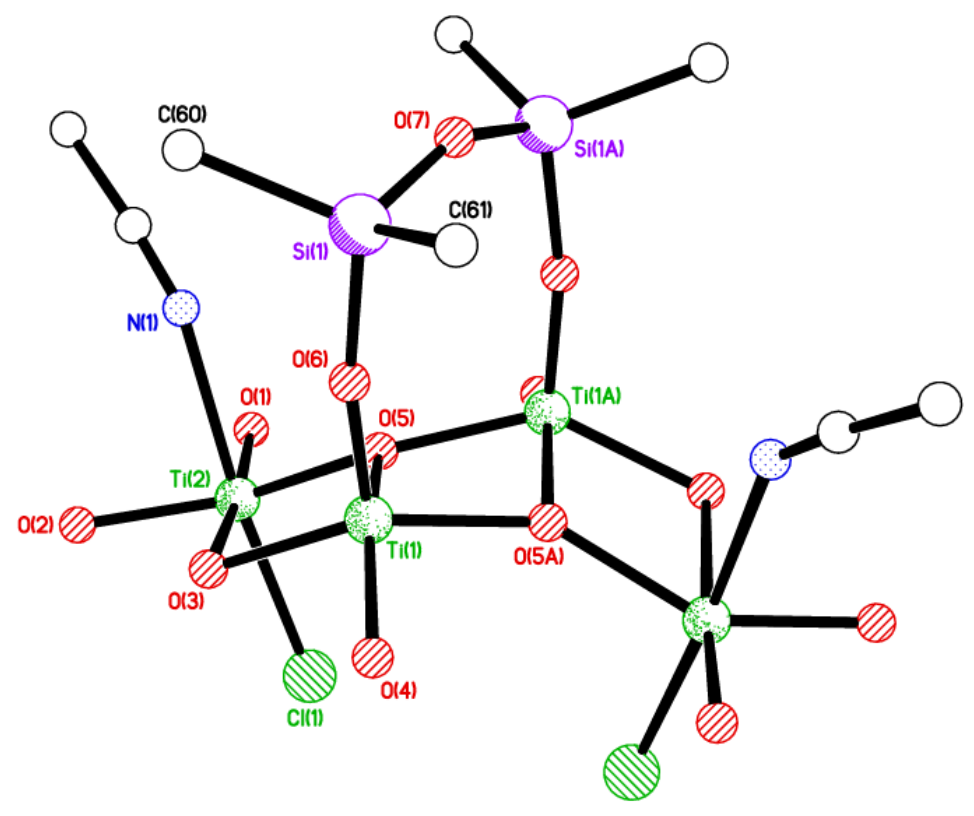

Figure 6. View of the core $\mathrm{Ti}_{4} \mathrm{O}_{4}$ ladder moiety present in $(3 \cdot \mathbf{1 0 M e C N})$ showing the molecule with the disiloxane bridge, two chlorides, and two MeCNs.

\section{Cytotoxicity studies}


The complexes presented were tested for cytotoxicity against a tumour cell line to see if the compounds had anticancer properties in their current form. The cytotoxicity values were measured using a cell viability assay. It should be noted that in in vivo and clinical tests formulation is key for cytotoxicity, especially for stable compounds. It has been observed in previous studies that the time the titanium compounds remain in solution can have an impact on the properties as hydrolysis occurs to form insoluble materials.

Complexes (1) - (3) were tested for their anti-proliferative activity against U-87 cells. These cells were incubated for $72 \mathrm{~h}$ before determining their mitochondrial based reduction of a tetrazolium dye (MTS) to a formazan product which absorbs at $490 \mathrm{~nm}$. This experiment was carried out over a range of concentrations to determine the amount of compound required to reduce cell growth by $50 \%$ (cytotoxic concentration, $\mathrm{CC}_{50}$ ). All compounds in this study are relatively non-toxic with $\mathrm{CC}_{50}$ values in the range 111-186 $\mu \mathrm{M}$. Dose response curves for treatment of U-87 cells with compounds (1) - (3) are shown in Figure 7. 


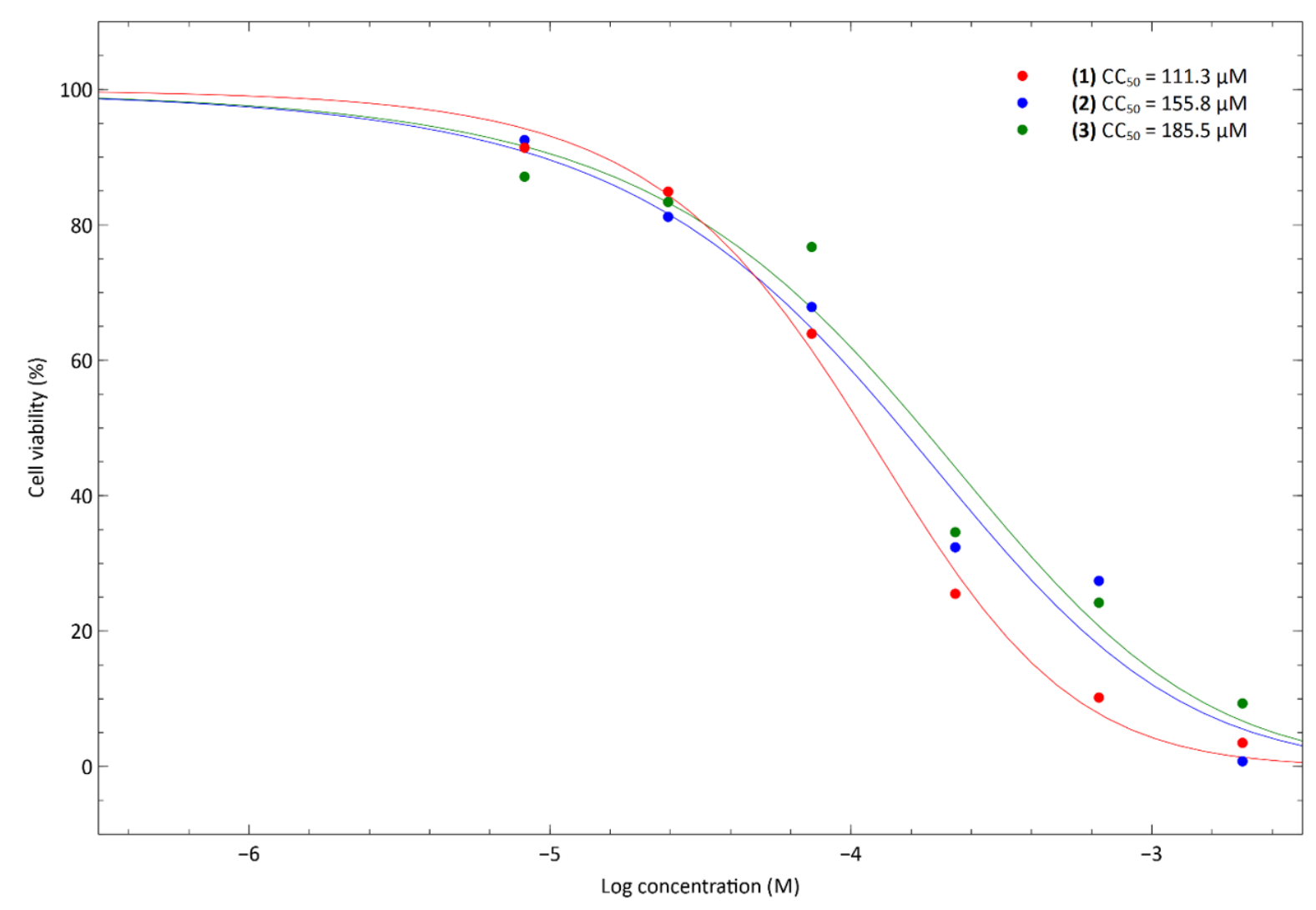

Figure 7. Dose response curve for 1, 2 and 3 showing the cell viability of MCF-7 cells on exposure to increasing concentrations of the titanium calixarene compounds. The $\mathrm{CC}_{50}$ values show the concentrations at which $50 \%$ of the cell population is no longer viable based on the curves plotted.

When compared with some titanium based anti-cancer agents, there are more effective monomeric compounds in the literature, particularly among the phenolato derivatives.[10] As a comparator, cisplatin, gives IC50 values between $10-20 \mu \mathrm{M}$ depending on which cell line the assay is run. A bis( $\beta$-diketonato)titanium complex ((bzac) $\left.)_{2} \mathrm{Ti}(\mathrm{OiPr})_{2}\right)$ shows an $\mathrm{IC}_{50}$ value between $11-12 \mu \mathrm{M}$ and a series of Ti-SALAN complexes (Chart 1 ) gives $\mathrm{IC}_{50}$ values from 1 - $10 \mu \mathrm{M}$. Table 1 summarises the $\mathrm{CC}_{50}$ values of the complexes synthesised and the $\mathrm{IC}_{50}$ values of selected Ti based anticancer agents $[10(\mathrm{a})]$. 
It is interesting to note the variation in compound properties relative to formulation and the relationship between hydrolytic stability and cytotoxicity. [10(b,c,d)] For example, it has been shown for some of the titanium(IV) salan compounds that switching a 2,4-di-tert-butyl phenol component to a 2,4-dimethyl phenol component activates the compounds against cancer cell lines by targeting of the cytoskeleton. [10(a)] Despite the lack of cytotoxic properties in this assay it is likely that modification of the structures and tuning of the stability could be combined with suitable formulation to deliver bioactive compounds. It is also worth noting that other mechanisms can give anticancer activities that would only become apparent in in vivo studies. Further research is required to determine optimal structural types for titanium(IV) calixarenes in biological applications. It would also be of interest to screen the compounds in antimicrobial analyses to determine activity against different organisms.

\begin{tabular}{cc}
\hline Complex & $\mathrm{CC}_{50}(\mu \mathrm{M})$ \\
\hline $\mathbf{( 1 )}$ & $111.3(\mathrm{U}-87)$ \\
$\mathbf{( 2 )}$ & $155.8(\mathrm{U}-87)$ \\
$\mathbf{( 3 )}$ & $185.5(\mathrm{U}-87)$ \\
\hline Known Compound & $\left.\mathrm{IC}_{50}(\mu \mathrm{M})\right)^{[11]}$ \\
\hline Cisplatin & $20(\mathrm{HT}-29), 19(\mathrm{OVCAR}-1)$ \\
$\mathrm{Cp}_{2} \mathrm{TiCl}_{2}$ & $520(\mathrm{HT}-29), 550$ (OVCAR-1) \\
$(\mathrm{bzac})_{2} \mathrm{Ti}_{(\mathrm{Oipr})}$ & $11.6(\mathrm{HT}-29), 11.5$ (OVCAR-1) \\
$\mathrm{Lig}^{1} \mathrm{Ti}(\mathrm{OArMe})_{2}$ & $10(\mathrm{HT}-29), 9$ (OVCAR-1) \\
$\mathrm{Lig}^{2} \mathrm{Ti}\left(\mathrm{OArMe}_{2}\right)_{2}$ & $3.5(\mathrm{HT}-29), 3.3$ (OVCAR-1) \\
$\mathrm{Lig}^{3} \mathrm{Ti}(\mathrm{OArMe})_{2}$ & $1.2(\mathrm{HT}-29), 1.0$ (OVCAR-1)
\end{tabular}

Table 1 - $\mathrm{CC}_{50}(\mu \mathrm{M})$ values of the Ti complexes synthesised and $\mathrm{IC}_{50}(\mu \mathrm{M})$ values of a selected Ti complexes.

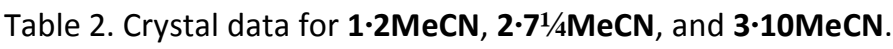

\begin{tabular}{cccc}
\hline Compound & $\mathbf{1 \cdot 2 M e C N}$ & $\mathbf{2 \cdot 7 1} / 4 \mathrm{MeCN}$ & $\mathbf{3 \cdot 1 0 M e C N}$ \\
\hline \multirow{3}{*}{ Formula } & & & {$\left[\mathrm{C}_{92} \mathrm{H}_{110} \mathrm{Cl}_{4} \mathrm{~N}_{2} \mathrm{O}_{10} \mathrm{Ti}_{4}\right]_{0.346}$} \\
& $\mathrm{C}_{54} \mathrm{H}_{74} \mathrm{Cl}_{2} \mathrm{O}_{4} \mathrm{Ti} \cdot 2 \mathrm{MeCN}$ & $\mathrm{C}_{98} \mathrm{H}_{127} \mathrm{ClO}_{9} \mathrm{Ti}_{2} \cdot 7.25(\mathrm{MeN})$ & {$\left[\mathrm{C}_{96} \mathrm{H}_{122} \mathrm{Cl}_{2} \mathrm{~N}_{2} \mathrm{O}_{13} \mathrm{Si}_{2} \mathrm{Ti}_{4}\right]_{0.654}$} \\
& & $10 \mathrm{MeCN}$
\end{tabular}


Formula weight

Crystal system

Space group

Unit cell dimensions
a $(\AA)$
$b(\AA)$
$c(\AA)$
$B(\AA)$
$V\left(\AA^{3}\right)$

$Z$

Temperature (K)

Wavelength $(\AA ̊)$

Calculated density $\left(\mathrm{Mg} \mathrm{m}^{-3}\right)$

Absorption

coefficient $\left(\mathrm{mm}^{-1}\right)$

Transmission

factors (min/max)

Crystal size $\left(\mathrm{mm}^{3}\right)$

$\vartheta(\max )\left({ }^{\circ}\right)$

Reflections

measured

Unique reflections

$$
R_{\text {int }}
$$

Reflections with $F^{2}>$ $2 \sigma\left(F^{2}\right)$

Number of

parameters

$R_{1}\left[F^{2}>2 \sigma\left(F^{2}\right)\right]$

$w R_{2}$ (all data)

GOOF, $S$

Largest difference

peak and hole (e $\AA^{\text {- }}$
988.0

Monoclinic

A2

17.2312(16)

$12.1620(8)$

27.103(2)

101.229(9)

5571.2(8)

4

140(2)

0.71073

1.178

0.30

0.914 and 0.974

$0.31 \times 0.21 \times 0.09$

22.5

30661

7245

0.144

3472

592

0.067

0.144

0.82

0.42 and -0.27
1877.88

Monoclinic

$P 2_{1} / n$

26.816(2)

13.2305(9)

$32.648(3)$

104.480(3)

$11215.2(15)$

4

120(2)

0.71073

1.112

0.22

0.940 and 0.993

$0.28 \times 0.09 \times 0.03$

22.5

35666

12068

0.087

7470

1299

0.122

0.275

1.06

0.50 and -0.38
2207.32

Monoclinic

C2/c

31.7283(3)

14.26944(14)

28.7967(3)

111.2143(12)

124154.1(2)

4

100(2)

0.71073

1.206

0.39

0.863 and 1.000

$0.35 \times 0.12 \times 0.03$

27.5

97082

13919

0.026

13137

804

0.057

0.147

1.18

1.01 and -0.65 


\section{Conclusion}

Three titanocalixarene complexes have been synthesised, characterised and screened for their anti-proliferative activity. The biological screening assay gives $\mathrm{CC}_{50}$ values that did not show significant anticancer activity for these compounds against the breast cancer cell line tested (U87). However, alternate formulation of the compounds or minor structural changes may alter their intracellular distribution and capability to form bioactive clusters. Calixarenes present a suitable framework for modification and so further investigation is required of alternate derivatives and formulation.

\section{Experimental section}

\section{General remarks}

NMR spectra were recorded on a Jeol JNM ECP400 spectrometer and a Jeol JNMLA400, with TMS $\delta_{\mathrm{H}}=0 \mathrm{ppm}$ as the internal standard or residual protic solvent $\left[\mathrm{CDCl}_{3}, \delta_{\mathrm{H}}=7.26\right]$. Chemical shifts are given in ppm $(\delta)$ and coupling constants $(J)$ are given in Hertz (Hz). Peak types in the spectra are denoted by the following notations: broad (br), singlet (s), doublet (d), triplet (t), quartet (q), quintet (quin), sextet (sex), and multiplet (m). Elemental analyses were carried out by staff at the University of Hull. Infrared spectra were recorded on a Nicolet iS5 FT-IR spectrometer. Mass spectra were obtained from the EPSRC National Mass Spectrometry Service Unit, Swansea University.

5,11,17,23-tetra-tert-butyl-dihydroxy-26,28-bis(2-pentoxy)calix[4]arene $\left(\mathrm{L}(\mathrm{OH})_{2}(\mathrm{Opentyl})_{2}\right) \quad$ and $\quad 49,50,51,52,53,54,55,56-$ octapropoxycalix[8]arene (L'(Opropyl)8) were prepared using the previously reported methods. [3b, 11] $\mathrm{TiCl}_{4}$ (1M in dichloromethane) was obtained from Sigma-Aldrich Company Ltd. and used as received. 


\section{Synthesis of $\left[\mathrm{TiCl}_{2} \mathrm{~L}(\mathrm{O})_{2}(\mathrm{Opentyl})_{2}\right](1)$}

To a solution of 5,11,17,23-tetra-tert-butyl-25,27-bis(pentoxy)-26,28dihydroxycalix[4]arene (2.5 g, $3.2 \mathrm{mmol})$ in warm, anhydrous toluene (50 mL) was added titanium(IV) chloride (1.0 M in toluene, $3.2 \mathrm{~mL}, 3.2 \mathrm{mmol})$. The resulting deep red solution was stirred at reflux for $6 \mathrm{~h}$ under a nitrogen atmosphere. The volatiles were then removed in vacuo and the residue was extracted into warm anhydrous acetonitrile $(20 \mathrm{~mL})$. The resulting solution was filtered under nitrogen whilst still warm and allowed to cool to room temperature. The solution was left to stand at ambient temperature and over the course of six to seven days dark red crystals were deposited. The remaining solution was decanted and further crops of crystals were obtained from this solution to give a total yield of $1.22 \mathrm{~g}$ (42.5\%). ${ }^{1} \mathrm{H}$ NMR (400 MHz; $\mathrm{CDCl}_{3}$; sample dried in-vacuo for 12 h, -2MeCN) $\delta: 7.19(4 \mathrm{H}, \mathrm{s}, \operatorname{Aryl} H), 6.89(4 \mathrm{H}$, s, Aryl $H$ ), 5.05 (4 H, t, $\left.J=8, \mathrm{OCH}_{2} \mathrm{CH}_{2}\right), 4.89\left(4 \mathrm{H}, \mathrm{d}, J=12\right.$, endo- $\left.\mathrm{CH}_{2}\right), 3.25(4 \mathrm{H}, \mathrm{d}$, $J=12$, exo- $\left.\mathrm{CH}_{2}\right), 2.03\left(4 \mathrm{H}, \mathrm{m}, \mathrm{OCH}_{2} \mathrm{CH}_{2} \mathrm{CH}_{2} \mathrm{CH}_{2} \mathrm{CH}_{3}\right), 1.42$ (18 H, s, $\left.\left(\mathrm{C}\left(\mathrm{CH}_{3}\right)_{3}\right)\right)$, $1.03\left(8 \mathrm{H}, \mathrm{m}, \mathrm{OCH}_{2} \mathrm{CH}_{2} \mathrm{CH}_{2} \mathrm{CH}_{2} \mathrm{CH}_{3}\right), 0.70\left(18 \mathrm{H}, \mathrm{s},\left(\mathrm{C}\left(\mathrm{CH}_{3}\right)_{3}\right)\right), 0.69(6 \mathrm{H}, \mathrm{t}, J=8$, $\mathrm{CH}_{2} \mathrm{CH}_{3}$ ). MALDI-MS m/z $780.38[\mathrm{M}+\mathrm{H}]^{+}$. Found: C, 70.58; H, 8.40; N, 2.71\%. Calcd. for $\mathrm{C}_{54} \mathrm{H}_{74} \mathrm{Cl}_{2} \mathrm{O}_{4} \mathrm{Ti} \cdot 2\left(\mathrm{CH}_{3} \mathrm{CN}\right)$ : C, 70.51; H, 8.16; N, 2.84\%. IR $\left(v_{\max } / \mathrm{cm}^{-1}\right)$ 2954 (w), 2923 (s), 2854 (m), 2360 (w), 1459 (s), 1377 (s), 1302 (w), 1260 (s), 1200 (w), 1090 (s), 1019 (s), $871(\mathrm{w}), 798$ (s), 721 (m), 668 (w), $618(\mathrm{w}), 571(\mathrm{~m}), 525(\mathrm{~m})$, 497 (m), 453 (m), 424 (s).

\section{Synthesis of $\left\{\left[\mathrm{TiL}(\mathrm{O})_{3}(\mathrm{Opentyl})\right]_{2}(\mu-\mathrm{OH})(\mu-\mathrm{Cl})\right\}(2)$}

A sample of 1 ( $0.50 \mathrm{~g}, 0.60 \mathrm{mmol}$ ) was exposed to atmospheric conditions for $2 \mathrm{~h}$. The resulting solid was then extracted into warm, anhydrous acetonitrile (10 mL) and 
filtered under a nitrogen atmosphere. The solution was left to stand at ambient temperature. Over the course of three to four days small orange/red prisms were deposited (0.18 g, 41.3\%). ${ }^{1} \mathrm{H}$ NMR (400 MHz; $\mathrm{CDCl}_{3}$; sample dried in-vacuo for 12 h, -7.25MeCN) $\delta: 7.02(4 \mathrm{H}, \mathrm{s}, \operatorname{Aryl} H), 6.74(4 \mathrm{H}, \mathrm{s}, \operatorname{Aryl} H), 5.13(2 \mathrm{H}, \mathrm{t}, J=8$, $\mathrm{OCH}_{2} \mathrm{CH}_{2}$ ), 4.95 (4 H, d, $J=12$, endo- $\mathrm{CH}_{2}$ ), 3.25 (4 H, d, $J=12$, exo-CH 2$), 2.78$ (2 H, m, $\left.\mathrm{OCH}_{2} \mathrm{CH}_{2} \mathrm{CH}_{2} \mathrm{CH}_{2} \mathrm{CH}_{3}\right), \quad 1.35\left(18 \mathrm{H}, \quad \mathrm{s}, \quad\left(\mathrm{C}\left(\mathrm{CH}_{3}\right)_{3}\right)\right), \quad 0.92 \quad(4 \mathrm{H}, \quad \mathrm{m}$, $\left.\mathrm{OCH}_{2} \mathrm{CH}_{2} \mathrm{CH}_{2} \mathrm{CH}_{2} \mathrm{CH}_{3}\right), 0.84\left(18 \mathrm{H}, \mathrm{s},\left(\mathrm{C}\left(\mathrm{CH}_{3}\right)_{3}\right)\right), 0.58\left(3 \mathrm{H}, \mathrm{t}, J=8, \mathrm{CH}_{2} \mathrm{CH}_{3}\right)$. MALDI-MS m/z 1579.89 $[\mathrm{M}+\mathrm{H}]^{+}$. Found: C, 74.02; H, 8.01; N, 1.34\%. Calcd. for $\mathrm{C}_{98} \mathrm{H}_{127} \mathrm{ClO}_{9} \mathrm{Ti}_{2} \cdot 1.5\left(\mathrm{CH}_{3} \mathrm{CN}\right): \mathrm{C}, 73.89 ; \mathrm{H}, 8.07 ; \mathrm{N}, 1.28 \%$. IR $\left(v_{\max } / \mathrm{cm}^{-1}\right) 2954(\mathrm{w})$, 2924 (s), 2854 (m), 2726 (w), 1459 (s), 1377 (s), 1304 (w), 1261 (m), 1209 (w), 1154 (w), $1093(\mathrm{~m}), 1019(\mathrm{~m}), 968(\mathrm{w}), 936(\mathrm{w}), 918(\mathrm{w}), 889(\mathrm{w}), 873(\mathrm{w}), 796(\mathrm{~m}), 721$ (m), $555(\mathrm{w})$.

\section{Synthesis of $0.346[\mathrm{Ti}(\mathrm{NCMe}) \mathrm{Cl}]_{2}[\mathrm{Ti}]_{2}[\mu-\mathrm{O}]_{2}[\mathrm{Cl}][5,11,17,23,29,35,41,47-$ tetra-tert-butyl-} 49,50,51,52,53,54,55,56-octaoxocalix $[8]$ arene $]: 0.654[\mathrm{Ti}(\mathrm{NCMe}) \mathrm{Cl}]_{2}[\mathrm{Ti}]_{2}[\mu-\mathrm{O}]_{2}[\mu-$ $\left.\mathrm{OSi}\left(\mathrm{CH}_{3}\right)_{2} \mathrm{OSi}\left(\mathrm{CH}_{3}\right)_{2} \mathrm{O}\right][5,11,17,23,29,35,41,47$-tetra-tert-butyl-49,50,51,52,53,54,55,56octaoxocalix[8]arene] (3)

To a suspension of $\mathrm{L}^{\prime}($ Opropyl) 8 (2.00 g, $1.22 \mathrm{mmol})$ in anhydrous toluene $(25 \mathrm{~mL})$ was added titanium(IV) chloride (1.0 $\mathrm{M}$ in toluene, $5.00 \mathrm{~mL}, 5.00 \mathrm{mmol})$. The resulting deep red mixture was refluxed for $16 \mathrm{~h}$ under an inert atmosphere. The volatiles were then removed in vacuo and the resulting residue was extracted into warm, anhydrous acetonitrile (20 $\mathrm{mL})$. The solution was filtered whilst warm under inert conditions and the filtrate was allowed to cool. The filtrate was left to stand for 7 days at ambient temperature during which time red needles of the co-crystallised compounds formed (0.96 g, 43\%). $\delta_{\mathrm{H}}\left(400 \mathrm{MHz}\right.$; $\mathrm{CDCl}_{3}$; sample dried 
in-vacuo for 12h, -10MeCN) 7.26 (2 H, d, $J=4$, ArylH), 7.23 (2 H, d, $J=4$, ArylH), 7.21 (2 H, d, $J=4$, Aryl $H$ ), 7.16 (4 H, m, ArylH), 6.84-6.82 (4 H, 2x m, ArylH), 4.99 (1 H, d, J 12.0 Hz, endo- $\left.\mathrm{CH}_{2}\right), 4.88\left(1 \mathrm{H}, \mathrm{d}, \mathrm{J} 12.0 \mathrm{~Hz}\right.$, endo- $\left.\mathrm{CH}_{2}\right), 4.72\left(2 \mathrm{H}, \mathrm{d}, \mathrm{J} 16.0 \mathrm{~Hz}\right.$, endo- $\left.\mathrm{CH}_{2}\right)$, 4.64 (4 H, m, endo- $\left.\mathrm{CH}_{2}\right)$, 4.01-3.83 (2 H, m, exo- $\left.\mathrm{CH}_{2}\right), 3.59$ (1 H, d, J $12.0 \mathrm{~Hz}$, exo- $\left.\mathrm{CH}_{2}\right)$, 3.54 (1 H, d, J 12.0 Hz, exo-CH2), 3.36 (2 H, m, exo-CH2), 3.29 (2 H, d, J 12.0 Hz, exo-CH $\mathrm{CH}_{2}$, $1.35\left(18 \mathrm{H}, \mathrm{s}, \mathrm{C}\left(\mathrm{CH}_{3}\right)\right), 1.33\left(18 \mathrm{H}, \mathrm{s}, \mathrm{C}\left(\mathrm{CH}_{3}\right)\right), 1.18\left(18 \mathrm{H}, \mathrm{s}, \mathrm{C}\left(\mathrm{CH}_{3}\right)\right), 1.17(18 \mathrm{H}, \mathrm{s}$,

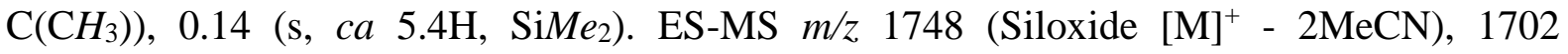
(Chloride $[\mathrm{M}]^{+} \quad-\quad \mathrm{Cl}$ ). Found: $\quad$ C, 61.02; H, 6.67; N, 1.49\%. [12] $\left[\mathrm{C}_{92} \mathrm{H}_{110} \mathrm{Cl}_{4} \mathrm{~N}_{2} \mathrm{O}_{10} \mathrm{Ti}_{4}\right]_{0.346}\left[\mathrm{C}_{96} \mathrm{H}_{122} \mathrm{Cl}_{2} \mathrm{~N}_{2} \mathrm{O}_{13} \mathrm{Si}_{2} \mathrm{Ti}_{4}\right]_{0.654}$ (sample dried in-vacuo for $12 \mathrm{~h}$, 10MeCN) requires: C, 63.24; H, 6.53; N, 1.56\%. IR ( $\left.v_{\max } / \mathrm{cm}^{-1}\right) 2962$ (m), 2905 (w), 1599 (w), 1452 (w), 1412 (w), 1361 (w), 1258 (s), 1191 (w), 1077 (m), 1011 (s), 863 (m), 789 (s), $696(\mathrm{~m}), 660(\mathrm{~m})$.

\section{Crystal structure determinations.}

Further details are given in Table 2, with special details pertaining to the three crystal structures summarised here. Crystals suitable for X-ray diffraction were grown by leaving saturated solutions of complexes (1) - (3) in anhydrous MeCN to stand at ambient temperature for several days. For $\mathbf{1 \cdot 2 M e C N}$, a deep red plate crystal was immediately coated in a thin layer of perfluoropolyether to avoid oxidation/hydrolysis of the product. An Oxford Diffraction Xcalibur CCD diffractometer was used for data collection. For $\mathbf{1} \mathbf{2} \mathbf{M e C N}$ the Platon Squeeze procedure was used to model one of the two unique MeCN molecules of crystallisation. [13 -15] For $\mathbf{2} \cdot \mathbf{7} \frac{1}{\mathbf{4}} \mathbf{M e C N}$ the Platon Squeeze procedure was used to model two of the unique MeCN molecules of crystallisation with some MeCNs modelled as point atoms but with two-fold disorder or with partial occupancy. There is disorder in three of the $t \mathrm{Bu}$ groups of the calixarenes with all of the methyl groups split over two sets positions: at $\mathrm{C}(18)$ 
the major occupancy $=67.6(18) \%$, at $\mathrm{C}(51)$ the major occupancy $=58.5(14) \%$, and at $\mathrm{C}(84)$ the major occupancy $=62(4) \%$. For $3 \cdot \mathbf{1 0 M e C N}$ data were collected using a Rigaku diffractometer with a rotating anode and Rigaku Saturn724+ detector. The complex lies on a centre of symmetry and is a solid-solution of the tetrachloride and dichloride/disiloxane complexes in a 34.6:65.4(3)\% ratio respectively. Several of the MeCNs of crystallisation were modelled as disordered or partially occupied, which is least partly a result of the main complex disorder and the different volumes occupied by the two forms.

\section{Cytotoxicity}

MTS assay is based upon the conversion of tetrazolium salt to into formazan in viable cells via mitochondrial dehydrogenase enzyme activity. The amount of formazan is directly proportional to the number of viable cells in the culture media. U-87 (homo sapiens brain glioblastoma) cells were seeded in 96 flat bottomed microtiter tissue culture plates with 1000 cells/well in $200 \mu \mathrm{L}$ media (RPMI $+1 \%$ glutamine $+10 \%$ FCS). The plates were incubated overnight in a $5 \% \mathrm{CO}_{2}$ incubator at $37^{\circ} \mathrm{C}$ to allow cells to adhere. The next day the media was removed from the wells and $100 \mu \mathrm{L}$ compound in media was added. Tested compounds were used in a range of concentrations from $0.91 \mu \mathrm{M}$ to $2 \mathrm{mM}$. The plates were then returned to a $5 \% \mathrm{CO}_{2}$ incubator for $72 \mathrm{~h}$ after which MTS reagent (Promega, UK) $20 \mu \mathrm{L}$ was added to each well and returned to the incubator at $37^{\circ} \mathrm{C}$ for a further $3 \mathrm{~h}$. Absorbance readings were taken at $490 \mathrm{~nm}$ using a Synergy HT microplate reader (Biotek, USA). Experiments were carried out in triplicate and subtracted from media only absorbance. $\mathrm{CC}_{50}$ values were obtained using GraphPad Prism 5 (GraphPad, USA) software. 


\section{Acknowledgements}

We would like to thank the EPSRC UK National Crystallography Service at the University of Southampton for the collection of data (structures $2 \cdot 71 / 4 \mathrm{MeCN} \&$ $3 \cdot 10 \mathrm{MeCN})$. The EPSRC Mass Spectrometry Service Centre at Swansea is thanked for the collection of mass spectra. CR thanks the Whitelaw Frater Cancer Trust for financial support.

\section{Notes and references}

$\ddagger$ CCDC 1554491-3 contain the supplementary crystallographic data for this paper. These data can be obtained free of charge from The Cambridge Crystallographic Data Centre via www.ccdc.cam.ac.uk/data_request/cif.

[1] (a) D. Peri, S. Meker, M. Shavit and E. Y. Tshuva, Chem. Eur. J. 2009, 15, 24032415. (b) S. B. Nimse and T. Kim, Chem. Soc. Rev. 2013, 42, 366-386.

[2] (a) M. J. Colston, H. C. Hailes, E. Stavropoulos, A. C. Hervé, G. Hervé, K. J. Goodworth, A. M. Hill, P. Jenner, P. D. Hart and R. E. Tascon, Infect. Immun. 2004, 72, 6318-6323. (b) C. Redshaw, X, Liu, S. Zhan, D. L. Hughes, H. Baillie-Johnson, M. R. J. Elsegood and S. H. Dale, Eur. J. Inorg. Chem. 2008, 2698-2712. (c) M. Mourer, H. Massimba Dibama, P. Constant, M. Daffé and J. B. Regnouf-de-Vains, Bioorg. Med. Chem. 2012, 20, 2035-2041. (d) Z. Luo, X. Xu, X. Zhang and L. Hu, Mini Rev. Med. Chem. 2013, 13, 1160-1165.

[3] (a) R. Lalor, H. Baillie-Johnson, C. Redshaw, S. E. Matthews, A. Mueller, J. Am. Chem. Soc. 2008, 130, 2892-2893. (b) C. Redshaw, M. R. J. Elsegood, J. A. Wright, H. Baillie-Johnson, T. Yamato, S. De Giovanni and A. Mueller, Chem. Commun. 2012, 48, 
1129-1131. (c) D. M. Miller-Shakesby, B. P. Burke, S. Nigam, G. J. Stasiuk, T. J. Prior, S. J. Archibald and C. Redshaw, Cryst. Eng. Comm. 2016, 18, 4977-4987.

[4] A. Tzubery and E. Y. Tshuva, Inorg. Chem. 2011, 50, 7946-7948.

[5] I. Haiduc, Organometallics 2004, 23, 3-8.

[6] For early examples, see (a) M. M. Olmstead, G. Sigel, H. Hope, X, Xu and P. P. Power, J. Am. Chem. Soc., 1985, 107, 8087-8091. (b) S. G. Bott, A. W. Coleman and J. L. Atwood, J. Chem. Soc., Chem. Commun., 1986, 610-611. (c) G. E. Hofmeister, E. Alvarado, J. A. Leary, D. I. Yoon and S. F. Pedersen, J. Am. Chem. Soc., 1990, 112, 8843-8851. (d) A. Zanotti-Gerosa, E. Solari, L. Giannini, C. Floriani, N. Re, A. Chiesi-Villa and C. Rizzoli, Inorg. Chimica Acta, 1998, 270, 298-311. (e) U. Radius and A. Friedrich, Z. Anorg. Allg. Chem. 1999, 625, 2154-2159. (f) U. Radius, Inorg. Chem. 2001, 40, 6637-6642. (g) W. Clegg, M. R. J. Elsegood, V. C. Gibson and C. Redshaw, Dalton Trans. 1998, 3037-3039. (h) U. Radius, Inorg. Chem. 2001, 40, 6637-6642. (i) F. A. Cotton, E. V. Dikarev, C. A. Murillo and M. A. Petrukhina, Inorg. Chim. Acta, 2002, 332, 41-46. (j) A. J. Petrella, N. K. Roberts, D. C. Craig, C. L. Raston and R. N. Lamb, Chem. Commun. 2003, 1014-1015. (k) A. J. Petrella, N. K. Roberts, C. L. Raston, M. Thornton-Pett and R. N. Lamb, Chem. Commun. 2003, 1238-1239.

[7] For catalytic use see (a) Y. Li, Y. S. Zheng and G. H. Xie, Acta Polym. Sin. 1998, 101-103. (b) O. V. Ozerov, N. P. Rath and F. T. Ladipo, J. Organomet. Chem. 1999, 586, 223-233. (c) O. V. Ozerov, F. T. Ladipo and B. O. Patrick, J. Am. Chem. Soc. 1999, 121, 7941-7942. (d) Y. Chen, Y. Zhang, Z. Shen and W. Sun, Acta. Polym. Sin. 2000, 2, 239-241. (e) A. Diaz-Barrios, J. Liscano, M. Trujillo, G. Agrifoglio, J. O. Matos, Assignee: Intevep S.A. U.S. Patent 5,767,034, 1998. (f) J. O. Matos, A. Diaz-Barrios, J. Liscano, M. Trujillo, G. Agrifoglio, Assignee: Intevep. S.A. European Patent EP1125951, 2001. (g) C. Capacchione, P. Neri and A. Proto, Inorg. Chem. Commun. 2003, 6, 339-342. (h) F. T. Ladipo, V. Sarveswaran, J. V. 
Kingston, R. A. Huyck, S. Y. Bylikin, S. D. Carr, R. Watts and S. Parkin, J. Organomet. Chem. 2004, 689, 502-514. (i) M. Frediani, D. Sémeril, A. Comucci, L. Bettucci, P. Frediani, L. Rosi, D. Matt, L. Toupet and W. Kaminsky, Macromol. Chem. Phys. 2007, 208, 938-945. (j) M. Frediani, D. Sémeril, A. Marrioti, L. Rosi, P. Frediani, L. Rosi, D. Matt and L. Toupet, Macromol. Rapid Commun. 2008, 29, 1554-1560. (k) J. Espinas, U. Darbost, J. Pelletier, E. Jeanneau, C. Duchamp, F. Bayard, O. Boyron, J.-P. Broyer, J. Thivolle-Cazat, J. -M. Basset, M. Taoufik and I. Bonnamour, Eur. J. Inorg. Chem. 2010, 1349-1359. (l) J. Bois, J. Espinas, U. Darbost, C. Felix, C. Duchamp, D. Bouchu, M. Taoufik and I. Bonnamour, J. Org. Chem. 2010, 75, 7550-7558. (m) J. D. Ryan, K. J. Gagnon, S. J. Teat and R. D. McIntosh, Chem. Commun. 2016, 52, 9071-9073.

[8] (a) J. M. Notestein, E. Iglesia and A. Katz, J. Am. Chem. Soc. 2004, 126, 16478-16486. (b) J. M. Notestein, L. R. Andrini, V. I. Kalchenko, F. G. Requejo, A. Katz and E. Iglesia, J. Am. Chem. Soc 2007, 129, 1122-1131. (c) J. M. Notestein, L. R. Andrini, F. G. Requejo, A. Katz and E. Iglesia, J. Am. Chem. Soc 2007, 129, 15585-15595. (d) Y. Guo, A. Solovyov, N. A. Grosso-Giordano, S.-J. Hwang and A. Katz, ACS Catal. 2016, 6, 7760-7768.

[9] H. Braband and U. Abram, Organometallics 2005, 24, 3362-3364.

[10] (a) T. Pesch, H. Schuhwerk, P. Wyrsch, T. Immel, W. Dirks, A. Burkle, T. Huhn and S. Beneke, Bmc Cancer 2016, 16:469. (b) S. Meker, O. Braitbard, K. MargulisGoshen, S. Magdassi, J. Hochman and E. Y. Tshuva, Molecules 2015, 20, 18526-18538. (c) R. Hernandez, J. Mendez, J. Lamboy, M. Torres, F. R. Roman and E. Melendez, Toxicology in Vitro 2010, 24, 178-183. (d) A. Tzubery and E. Y. Tshuva, Eur. J. Inorg. Chem. 2017, 1695-1705.

[11] J. Yi, K. Tang, S. Huang and K. Huang, Ind. J. Chem. 2008, 47B, 1435-1437. 
[12] Calixarenes can be difficult to combust during elemental analysis, and this has been reported previously, see for example C. Redshaw, D. Homden, D. L. Hughes, J. A. Wright and M. R. J. Elsegood, Dalton Trans. 2009, 1231-1242 and references therein.

[13] F. H. Allen, Acta Crystallgr., Sect B, 2002, 58, 380-388.

[14] A. L. Spek, Acta Crystallogr. Sect. A, 1990, 46, C34.

[15] P. v. d. Sluis and A.L. Spek, Acta Crystallogr. Sect. A, 1990, 46, 194-201. 